Prepared for the U.S. Department of Energy

under Contract DE-AC05-76RL01830

\title{
Hanford Technical Basis for Multiple Dosimetry Effective Dose Methodology
}

R. L. Hill

B. A. Rathbone

August 2010

Pacific Northwest

NATIONAL LABORATORY

Proudly Operated by Battelle Since 1965 


\title{
DISCLAIMER
}

This report was prepared as an account of work sponsored by an agency of the United States Government. Neither the United States Government nor any agency thereof, nor Battelle Memorial Institute, nor any of their employees, makes any warranty, express or implied, or assumes any legal liability or responsibility for the accuracy, completeness, or usefulness of any information, apparatus, product, or process disclosed, or represents that its use would not infringe privately owned rights. Reference herein to any specific commercial product, process, or service by trade name, trademark, manufacturer, or otherwise does not necessarily constitute or imply its endorsement, recommendation, or favoring by the United States Government or any agency thereof, or Battelle Memorial Institute. The views and opinions of authors expressed herein do not necessarily state or reflect those of the United States Government or any agency thereof.

\author{
PACIFIC NORTHWEST NATIONAL LABORATORY \\ operated by \\ BATTELLE \\ for the \\ UNITED STATES DEPARTMENT OF ENERGY \\ under Contract DE-AC05-76RL01830
}

Printed in the United States of America
Available to DOE and DOE contractors from the Office of Scientific and Technical Information,
P.O. Box 62, Oak Ridge, TN 37831-0062;
ph: (865) 576-8401
fax: $(865)$ 576-5728
email: reports@adonis.osti.gov

\begin{abstract}
Available to the public from the National Technical Information Service, U.S. Department of Commerce, 5285 Port Royal Rd., Springfield, VA 22161 ph: (800) 553-6847 fax: $(703) 605-6900$ email: orders@ntis.fedworld.gov online ordering: http://www.ntis.gov/ordering.htm
\end{abstract}

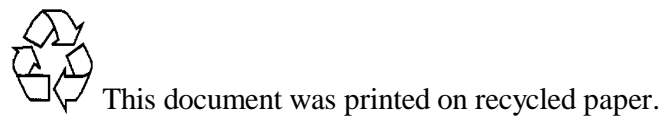




\section{Hanford Technical Basis for Multiple Dosimetry Effective Dose Methodology}

RL Hill

BA Rathbone

August 2010

Prepared for the U.S. Department of Energy

under Contract DE-AC05-76RL01830

Pacific Northwest National Laboratory

Richland, Washington 99352 


\section{HANFORD TECHNICAL BASIS FOR MULTIPLE DOSIMETRY EFFECTIVE DOSE METHODOLOGY}

\subsection{INTRODUCTION}

Under the 1998 revision to 10 CFR 835 (DOE 1998), the method used at Hanford for calculating whole body dose from multiple dosimeters worn during non-uniform irradiation was to calculate the effective dose equivalent (EDE) to the whole body using the compartmentalization method described in the 1997 ANSI/HPS N13.41 standard, "Criteria for Performing Multiple Dosimetry (ANSI 1997). In that standard, the compartment weighting factors were developed by summing the stochastic risk weighting factors from ICRP 26 (ICRP 1997) for the organs located within each given compartment. If organs resided in more than one compartment, the fraction of the total mass of the organ was used to apportion the contribution from that organ in the given compartment, based on information from ICRP 23 (ICRP 1974).

With the adoption of the ICRP 60 (ICRP 1991) methodology in the 2007 revision to 10 CFR 835 came changes that had a direct affect on the compartmentalization method described in the 1997 ANSI/HPS N13.41 standard, and, thus, to the method used at Hanford. The ANSI/HPS N13.41 standard committee is in the process of updating the standard, but the changes to the standard have not yet been approved. And, the drafts of the revision of the standard tend to align more with ICRP 60 than with the changes specified in the 2007 revision to 10 CFR 835 . Therefore, it was necessary for Hanford to independently develop a compartmental method for calculating effective dose (ED) from non-uniform external irradiation that utilized the tissue weighting factors and remainder organs specified in 10 CFR 835 (DOE 2007). The previous EDE methodology used for compliance with the 1998 revision of 10 CFR 835 was described in the "Hanford External Dosimetry Technical Basis Manual," PNL-MA-842, Rev. 0.2 (PNNL 2009). The current ED methodology used for compliance with the 2007 revision of 10 CFR 835 is described in "Hanford External Dosimetry Technical Basis Manual," PNL-MA-842, Rev. 1.1 (PNNL 2010).

\subsection{ASSUMPTIONS}

The following assumptions were used to develop the compartmental weighting factors to be used in calculating effective dose from use of multiple dosimeters.

\subsection{Information from 10 CFR 835}

The tissue weighting factors presented in the 2007 revision of 10 CFR 835 are given in Table 1.

Footnote \#1 to the "Tissue Weighting Factors for Various Organs and Tissues," table lists the ten organs to be considered as the "remainder" organs (see Table 2). This footnote also specifies that the equivalent dose to the remainder tissues $\left(\mathrm{H}_{\text {remainder }}\right)$ is normally calculated as the mass weighted mean dose to these ten organs and tissues. It should be noted that the ICRP 60-specified remainder organs include the upper large intestine (ULI) while 10 CFR 835 (2007) includes "extrathoracic airways" in place of "upper large intestine".

The remainder organ/tissue weighting factors were derived using masses of the organs/tissues specified in Footnote 1 to the 10 CFR 835.2 table, "Tissue Weighting Factors for Various Organs and Tissues," as follows:

$$
w_{T_{i}}=\frac{m_{T_{i}}}{m_{R O}} * 0.05
$$


Where: $\quad \mathrm{w}_{\mathrm{Ti}}=$ Remainder tissue/organ weighting factor for tissue $\left(\mathrm{T}_{\mathrm{i}}\right)$

$\mathrm{m}_{\mathrm{Ti}}=$ Mass of organ/tissue $(\mathrm{i}, \mathrm{g})$ from 10 CFR 835.2

$\mathrm{m}_{\mathrm{RO}}=$ Mass of all remainder organs $(30,759 \mathrm{~g})$

$0.05=$ Tissue weighting factor for remainder tissues/organs from 10 CFR 835.2

Table 1. Tissue Weighting Factors ${ }^{(a)}$

\begin{tabular}{||l|c|}
\hline \multicolumn{1}{|c|}{ Organ or Tissue $(\mathrm{T})$} & $\begin{array}{c}\text { Tissue Weighting } \\
\text { Factor }\left(\mathrm{w}_{\mathrm{T}}\right)\end{array}$ \\
\hline \hline Gonads & 0.20 \\
\hline Red Bone Marrow & 0.12 \\
\hline Colon & 0.12 \\
\hline Lungs & 0.12 \\
\hline Stomach & 0.12 \\
\hline Bladder & 0.05 \\
\hline Breast & 0.05 \\
\hline Liver & 0.05 \\
\hline Esophagus & 0.05 \\
\hline Thyroid & 0.05 \\
\hline Skin & 0.01 \\
\hline Bone Surfaces & 0.01 \\
\hline Remainder & (b) \\
\hline
\end{tabular}

a. From 10 CFR 835 (2007).

b. The derivation of the remainder tissue weighting factors for the organs/tissues specified in $10 \mathrm{CFR}$ 835.2 is given in Table 2.

Table 2. Tissue Weighting Factors for Remainder Tissues ${ }^{(a)}$

\begin{tabular}{|c|c|c|c|}
\hline Tissue or Organ (T) & $\begin{array}{l}\text { Tissue/Organ } \\
\text { Mass }\left(m_{\mathrm{T}}, \mathbf{g}\right)\end{array}$ & $\begin{array}{l}\text { Fraction of Total Remainder } \\
\text { Organs/Tissues }(\mathbf{F})^{(\mathbf{b})}\end{array}$ & $\begin{array}{l}\text { Tissue Weighting } \\
\text { Factor }\left(\mathbf{w}_{\mathrm{T}}\right)\end{array}$ \\
\hline Adrenals & 14 & $4.55 \mathrm{E}-04$ & $2.28 \mathrm{E}-05$ \\
\hline Brain & 1,400 & $4.55 \mathrm{E}-02$ & $2.28 \mathrm{E}-03$ \\
\hline Extrathoracic Airways $^{(\mathbf{c})}$ & 15 & $4.88 \mathrm{E}-04$ & $2.44 \mathrm{E}-05$ \\
\hline Small Intestine & 640 & $2.08 \mathrm{E}-02$ & $1.04 \mathrm{E}-03$ \\
\hline Kidneys & 310 & $1.01 \mathrm{E}-02$ & $5.04 \mathrm{E}-04$ \\
\hline Muscle & 28,000 & $9.10 \mathrm{E}-01$ & $4.55 \mathrm{E}-02$ \\
\hline Pancreas & 100 & $3.25 \mathrm{E}-03$ & $1.63 \mathrm{E}-04$ \\
\hline Spleen & 180 & $5.85 \mathrm{E}-03$ & $2.93 \mathrm{E}-04$ \\
\hline Thymus & 20 & $6.50 \mathrm{E}-04$ & $3.25 \mathrm{E}-05$ \\
\hline Uterus & 80 & $2.60 \mathrm{E}-03$ & $1.30 \mathrm{E}-04$ \\
\hline $\begin{array}{r}\text { All Remainder } \\
\text { Organs/Tissues }\left(\mathrm{m}_{\mathrm{RO}}\right)\end{array}$ & 30,759 & 1.00 & 0.05 \\
\hline
\end{tabular}

a. The listed remainder organs/tissues are from 10 CFR 835.2 (2007).

b. Fraction of total remainder tissue/organ mass is given by: $F_{T_{i}}=\frac{m_{T_{i}}}{m_{R O}}$.

c. For 10 CFR 835 (2007), extrathoracic airways are used instead of the upper large intestine from ICRP 60 (1991).

\subsection{Other Assumptions}

When defining the compartment using traditional body segments, there are circumstances where some organs or tissues reside in more than one compartment. For tissues such as skin, muscle, red bone 
marrow, and bone surfaces, the weighting factor was divided into the different compartments using information from ICRP 23 (1974).

The term "proximal extremities" is used to represent the upper arms from shoulder to elbow and upper legs from hip to knee consistent with the draft revision to the ANSI/HPS N13.41 standard.

For red bone marrow, the apportionment was based on the estimated fraction of the total mass of the tissue contained in each compartment. The red bone marrow in the extremities is divided between the thorax and abdomen compartments since the head and neck of the main bones are closely aligned with skeletal structures of the scapulae and clavicles of the shoulder and pelvic bones in the abdomen. From a practical perspective, these are associated with dosimeters worn on the thorax or abdomen. Therefore, the extremity compartment factors are derived from muscle, skin, and bone surfaces only. This approach aligns with the approach taken in the draft revision to the ANSI/HPS N13.41 standard and is a conservative approach since the thorax and abdomen have higher compartment weighting factors than does the extremity compartment.

For the liver and stomach, the tissue weighting factors were divided assuming $60 \%$ in the abdomen and $40 \%$ in the thorax. The esophagus, which extends from the pharynx to the stomach was split with $60 \%$ in the head/neck compartment and $40 \%$ in the thorax compartment.

For the calculation of effective dose from non-penetrating radiations for the new compartment model, the maximum [shallow - deep] dose result from a dosimeter in each compartment is used to calculate the skin tissue's contribution to the effective dose.

\subsection{DEVELOPMENT OF COMPARTMENT WEIGHTING FACTORS}

\subsection{Calculations}

ANSI/HPS N13.41 - 1997 provides a table showing the compartments used and the compartment weighting factors that are based on the ICRP 26. The same compartments (head/neck, thorax, abdomen, upper right arm, upper left arm, right thigh, left thigh, see Figure 1) were designated for assessing effective dose from external sources in a manner that complies with the 2007 revision to 10 CFR 835 . For each compartment, the compartment weighting factor $\mathrm{CF}$, to be used with dosimeter results is calculated as follows:

$$
C F=\sum_{i} W_{T i} * M F_{i}
$$

Where:

$W_{T i}=$ tissue weighting factor for tissue $\mathrm{i}$.

$M F_{i}=$ mass fraction of tissue i residing in the compartment

Summation is performed over all tissues $i$, including remainder tissues

The revised compartment weighting factors are shown in Table 3. 


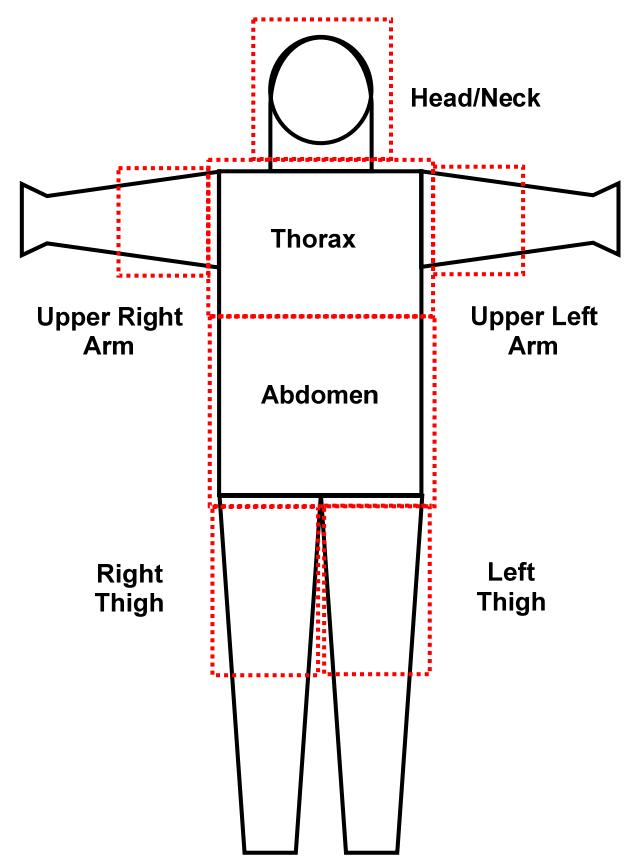

Figure 1. Diagram of Whole Body Compartments

\section{Whole Body Compartment Factors}

Table 3. Whole Body Compartment Weighting Factors (CF)

\begin{tabular}{|l|c|c|c||}
\hline \multicolumn{1}{|c|}{ Compartment } & $\begin{array}{c}\mathrm{CF}_{\gamma} \text { for } \mathrm{H}_{\mathrm{p}}(10)_{\gamma} \\
\text { Dosimeter } \\
\text { Results }\end{array}$ & $\begin{array}{c}\mathrm{CF}_{\eta} \text { for } \mathrm{H}_{\mathrm{p}}(10)_{\eta} \\
\text { Dosimeter } \\
\text { Results }\end{array}$ & $\begin{array}{c}\mathrm{CF}_{\beta} \text { for } \\
\mathrm{H}_{\mathrm{p}}(0.07)_{\beta} \text { Dosimeter } \\
\text { Results }\end{array}$ \\
\hline \hline Head and Neck & 0.108 & 0.108 & 0.0012 \\
\hline Thorax, above the diaphragm & 0.307 & 0.307 & 0.0028 \\
\hline Abdomen, including pelvis & 0.561 & 0.561 & 0.0028 \\
\hline Upper Right Arm & 0.006 & 0.006 & 0.0008 \\
\hline Upper Left Arm & 0.006 & 0.006 & 0.0008 \\
\hline Right Thigh & 0.006 & 0.006 & 0.0008 \\
\hline Left Thigh & 0.006 & 0.006 & 0.0008 \\
\hline
\end{tabular}

a. $\quad \mathrm{H}_{\mathrm{p}}(0.07)_{\beta} \equiv\left[\mathrm{H}_{\mathrm{p}}(0.07)-\mathrm{H}_{\mathrm{p}}(10)_{\gamma}\right]$ The difference represents additional dose to the skin (primarily from beta particles) not accounted for in the $\mathrm{H}_{\mathrm{p}}(10)_{\gamma}$ and $\mathrm{H}_{\mathrm{p}}(10)_{\eta}$ doses.

The compartment weighting factors (CFs) were developed by first determining the 10 CFR 835 tissues of interest, including remainder tissues. That assessment is described in the previous section and shown in Tables 1 and 2. The next step was to determine the mass fraction of each organ or tissue that resides in each ANSI/HPS N13.41 designated body compartment. Table 4 summarizes the mass fraction of each specified organ/tissue in the four main compartments, where upper right and left arm, and right and left thigh are grouped into a proximal extremity compartment. For each organ, $100 \%$ (or a sum of fractions equal to 1) is accounted for in one or more of the compartments. 
Table 4. Organ/Tissue Mass Fraction Residing in Body Compartments

\begin{tabular}{|c|c|c|c|c|c|}
\hline \multirow[b]{2}{*}{ Organ/Tissue } & \multicolumn{5}{|c|}{ Mass Fraction (MF) of Tissue Residing in Compartment } \\
\hline & $\begin{array}{c}\text { Head/ } \\
\text { Neck } \\
\end{array}$ & Thorax & Abdomen & $\begin{array}{c}\text { Proximal } \\
\text { Extremities }\end{array}$ & $\begin{array}{c}\text { Sum of Tissue } \\
\text { Fractions } \\
\end{array}$ \\
\hline Gonads & & & 1.00 & & 1.00 \\
\hline Red Bone Marrow & 0.15 & 0.30 & 0.55 & & 1.00 \\
\hline Colon & & & 1.00 & & 1.00 \\
\hline Lungs & & 1.00 & & & 1.00 \\
\hline Stomach & & 0.40 & 0.60 & & 1.00 \\
\hline Bladder & & & 1.00 & & 1.00 \\
\hline Breast & & 1.00 & & & 1.00 \\
\hline Liver & & 0.40 & 0.60 & & 1.00 \\
\hline Esophagus & 0.60 & 0.40 & & & 1.00 \\
\hline Thyroid & 1.00 & & & & 1.00 \\
\hline Skin ${ }^{(\mathbf{b})}$ & 0.12 & 0.28 & 0.28 & 0.32 & 1.00 \\
\hline Bone Surfaces & 0.20 & 0.15 & 0.15 & 0.50 & 1.00 \\
\hline Adrenals ${ }^{(\mathbf{c})}$ & & & 1.00 & & 1.00 \\
\hline Brain $^{(c)}$ & 1.00 & & & & 1.00 \\
\hline Extrathoracic ${ }^{(\mathbf{c}, \mathbf{d})}$ & 1.00 & & & & 1.00 \\
\hline Small Intestine ${ }^{(\mathrm{c})}$ & & & 1.00 & & 1.00 \\
\hline Kidneys ${ }^{(\mathbf{c})}$ & & & 1.00 & & 1.00 \\
\hline Muscle $^{(\mathbf{b}, \mathbf{c})}$ & 0.091 & 0.182 & 0.364 & 0.364 & 1.00 \\
\hline Pancreas ${ }^{(c)}$ & & & 1.00 & & 1.00 \\
\hline Spleen ${ }^{(c)}$ & & & 1.00 & & 1.00 \\
\hline Thymus ${ }^{(\mathbf{c})}$ & & 1.00 & & & 1.00 \\
\hline Uterus $^{(c)}$ & & & 1.00 & & 1.00 \\
\hline
\end{tabular}

a. The proximal extremities include the upper right and left arm, and right and left thigh.

b. The skin fraction used is taken as a fraction of the skin for [whole body - lower extremities]. The muscle fraction used is taken as a fraction of the muscle for [whole body - lower extremities].

c. The ten remainder organs/tissues as specified in 10 CFR 835.2 (2007).

d. The nose, nasal cavity, nasopharynx, oropharynx, and larynx are considered tissues of the extrathoracic region (ICRP 60, 1991). 
Table 5 provides a summary of the compartment weighting factors calculated using the tissue weighting factors and organ/tissues specified in 10 CFR 835.2 (2007) and the fraction of each organ/tissue in each compartment from Table 4. The sum of all CFs equals 1.0.

Table 5. Tissue Weighting x Mass Fraction

\begin{tabular}{|c|c|c|c|c|c|}
\hline \multirow[b]{2}{*}{ Organ/Tissue } & \multirow[b]{2}{*}{$\mathbf{W}_{T}{ }^{(\mathbf{a})}$} & \multicolumn{4}{|c|}{$\mathbf{W}_{\mathrm{T}} * \mathbf{M F}$} \\
\hline & & $\begin{array}{l}\text { Head/ } \\
\text { Neck }\end{array}$ & Thorax & Abdomen & $\begin{array}{c}\text { Proximal } \\
\text { Extremities }\end{array}$ \\
\hline Gonads & 0.2 & & & 0.2 & \\
\hline Red Bone Marrow & 0.12 & 0.018 & 0.036 & 0.066 & \\
\hline Colon & 0.12 & & & 0.12 & \\
\hline Lungs & 0.12 & & 0.12 & & \\
\hline Stomach & 0.12 & & 0.048 & 0.072 & \\
\hline Bladder & 0.05 & & & 0.05 & \\
\hline Breast & 0.05 & & 0.050 & & \\
\hline Liver & 0.05 & & 0.020 & 0.030 & \\
\hline Esophagus & 0.05 & 0.030 & 0.020 & & \\
\hline Thyroid & 0.05 & 0.050 & & & \\
\hline Skin & 0.01 & 0.0012 & 0.0028 & 0.0028 & 0.0032 \\
\hline Bone Surfaces & 0.01 & 0.0020 & 0.0015 & 0.0015 & 0.0050 \\
\hline Adrenals ${ }^{(\mathbf{c})}$ & $2.28 \mathrm{E}-05$ & & & $2.28 \mathrm{E}-05$ & \\
\hline Brain $^{(c)}$ & $2.28 \mathrm{E}-03$ & $2.28 \mathrm{E}-03$ & & & \\
\hline Extrathoracic ${ }^{(\mathbf{c}, \mathbf{d})}$ & $2.44 \mathrm{E}-05$ & $2.44 \mathrm{E}-05$ & & & \\
\hline Small Intestine ${ }^{(c)}$ & $1.04 \mathrm{E}-03$ & & & $1.04 \mathrm{E}-03$ & \\
\hline Kidneys ${ }^{(c)}$ & $5.04 \mathrm{E}-04$ & & & $5.04 \mathrm{E}-04$ & \\
\hline Muscle $^{(c)}$ & $4.55 \mathrm{E}-02$ & 4.14E-03 & 8.28E-03 & $1.66 \mathrm{E}-02$ & $1.66 \mathrm{E}-02$ \\
\hline Pancreas ${ }^{(c)}$ & $1.63 \mathrm{E}-04$ & & & $1.63 \mathrm{E}-04$ & \\
\hline Spleen ${ }^{(c)}$ & $2.93 \mathrm{E}-04$ & & & $2.93 \mathrm{E}-04$ & \\
\hline Thymus ${ }^{(\mathbf{c})}$ & $3.25 \mathrm{E}-05$ & & $3.25 \mathrm{E}-05$ & & \\
\hline Uterus ${ }^{(\mathrm{c})}$ & $1.30 \mathrm{E}-04$ & & & $1.30 \mathrm{E}-04$ & \\
\hline \multicolumn{2}{|c|}{$\mathbf{C F}=\sum\left(\mathbf{W}_{\mathbf{T}} * \mathbf{M F}\right)^{(\mathrm{e})}$} & 0.108 & $\mathbf{0 . 3 0 7}$ & 0.561 & 0.0248 \\
\hline
\end{tabular}

a. Tissue weighting factors are from 10 CFR 835.2 and are calculated for the ten remainder organs as summarized in Table 2 .

b. The proximal extremities include the upper right and left arm and right and left thigh.

c. The ten remainder organs/tissues.

d. The nose, nasal cavity, nasopharynx, oropharynx, and larynx are considered tissues of the extrathoracic region (ICRP 60, 1991).

e. The compartment weighting factors (CF) are summarized in Table 3.

The CF for upper right and left arm, and right and left thigh are derived by dividing the proximal extremity CF equally into four portions, i.e., 0.0062 each. It is acknowledged that the skin, muscle, and bone surface tissue components for the thighs will be larger than that for the upper arms. However, for a whole body compartment with a low $\mathrm{CF}$, the difference in effective doses would be minimal. 


\section{$\underline{\text { Effective Dose Calculations }}$}

The external effective dose to the whole body from photons $\left(\mathrm{E}_{\gamma}\right)$ is calculated as follows:

$$
E_{\gamma}=\sum\left(D_{\gamma} * C F_{\gamma}\right)
$$

where: $\quad \mathrm{E}_{\gamma}=$ External effective dose to whole body from photons

$\mathrm{D}_{\gamma}=\mathrm{Hp}(10) \gamma$ for compartment (c)

$\mathrm{CF}_{\gamma}=$ Compartment factor for $\mathrm{Hp}(10) \gamma$ in compartment (c) from Table 3

Summation is performed over all compartments c.

The external effective dose to the whole body from neutrons $\left(E_{\eta}\right)$ is calculated as follows:

$$
E_{\eta}=\sum\left(D_{n} * C F_{n}\right)
$$

where: $\quad E_{\eta}=$ External effective dose to whole body from neutrons

$\mathrm{D}_{\eta}=\mathrm{Hp}(10) \eta$ for compartment (c).

$\mathrm{CF}_{\mathrm{n}}=$ Compartment factor for $\mathrm{Hp}(10) \eta$ in compartment (c) from Table 3

Summation is performed over all compartments c.

The external effective dose to the whole body from non-penetrating radiation (i.e. beta particles and nonpenetrating photons), is not accounted for in the calculation of $E_{\gamma}$ and $E_{\eta}$ above. This quantity is designated as $\mathrm{E}_{\beta}$ and is calculated as follows:

$$
E_{\beta}=\sum\left(D_{\beta} * C F_{\beta}\right)
$$

where: $\quad \mathrm{E}_{\beta}=$ External effective dose to whole body from beta particles (and non-penetrating photons)

$\mathrm{D}_{\beta} \quad=\mathrm{Hp}(0.07)_{\beta} \equiv[\mathrm{Hp}(0.07)-\mathrm{Hp}(10) \gamma]$ for compartment (c)

$\mathrm{CF}_{\beta}=$ Compartment weighting factor for $\mathrm{Hp}(0.07)_{\beta}$ in compartment (c) from Table 3

Summation is performed over all compartments c.

To determine the dose to a given compartment, the highest dosimeter result from that compartment is used. If the compartment was not monitored, the result from the nearest compartment monitored may be assigned. The total external effective dose for a multiple dosimeter pack would be the sum of the individual components as follows:

$$
\mathrm{E}_{\text {total }}=\mathrm{E}_{\gamma}+\mathrm{E}_{\eta}+\mathrm{E}_{\beta}
$$

\subsection{Comparisons}

The February 2009 draft revision of the ANSI/HPS N13.41 standard reports the revised CFs as being $0.11,0.30,0.57$, and 0.01 , respectively, for the head/neck, thorax, abdomen, and proximal extremity compartments (without separate factors for non-penetrating radiation). These values were calculated by the Standard Committee with the following assumptions or conditions:

- the ten remainder organs had equal tissue weighting factors of 0.005 , which sums to 0.05 ; 
- uses the upper large intestine from ICRP 60 instead of the extrathoracic airways that are used in 10 CFR 835; and

- only accounted for $35 \%$ of the muscle tissue.

For comparison with the revised Hanford compartment method developed here, $65 \%$ of the muscle tissue was assumed to be in the proximal extremity compartment for the draft ANSI/HPS method so that 100\% of the muscle is accounted for in the compartment model.

For further comparison, another recent draft study which used the MCNP code to tally doses for the organs/tissues in twelve different compartments (see Figure 2) over the whole body used the tissue weighting factors given in 10 CFR 835 (2007) to arrive at CFs of $\mathbf{0 . 0 8 , 0 . 2 9 , 0 . 6 2 , ~ a n d ~} \mathbf{0 . 0 1}$ for the head/neck, thorax, abdomen, and proximal extremity compartments. To compare with the new compartment model developed here, four compartments are combined to form the abdominal compartment and four compartments are combined to form the upper leg compartment for the MCNP study. This study also had different assumptions on allotment of organ/tissues in the various compartments. It is included here to help illustrate that the selection of body locations to be included in various whole body compartments has little effect on the values of the compartment weighting factors.

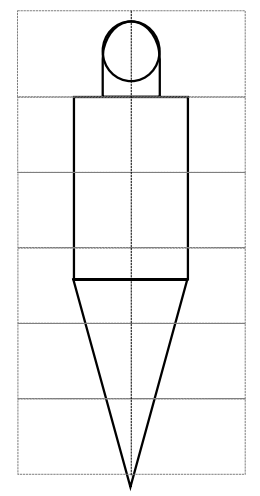

Figure 2. Diagram of Whole Body Compartments from Draft MCNP Study

\subsection{Example Calculation}

Example: Dosimeters worn on the chest, groin area, upper left leg and upper right leg have respective deep dose $\left[\mathrm{Hp}(10)_{\gamma}\right]$ dosimeter results of $84,121,170$, and $158 \mathrm{mrem}$; neutron doses $\left[\mathrm{Hp}(10)_{\eta}\right]$ of 0,27 , $0,21 \mathrm{mrem}$; and shallow dose $[\mathrm{Hp}(0.07)]$ dosimeter results of $110,173,167$, and $182 \mathrm{mrem}$. The effective dose $\left(\mathrm{E}_{\text {Total }}\right)$ is shown in Table 6 for the four different compartmentalization methods. If the current Hanford and ANSI/HPS N13.41 method and CFs were used (Table 6.B), the resulting effective dose would be 117 mrem. Using the February 2009 draft revision to the ANSI/HPS standard, the effective dose would be 120 mrem. Using the values from the draft MCNP compartment model, the effective dose would be $124 \mathrm{mrem}$. Using the revised Hanford methodology (Table 6.A), the resulting effective dose would be 106 mrem (from deep dose) $+15 \mathrm{mrem}$ (from neutron dose) $+0.3 \mathrm{mrem}$ (from shallow dose $)=121 \mathrm{mrem}$. This calculated value of $121 \mathrm{mrem}$ is higher than that for the chest dosimeter result of 84 mrem and, thus, would be used for the effective dose of record. 


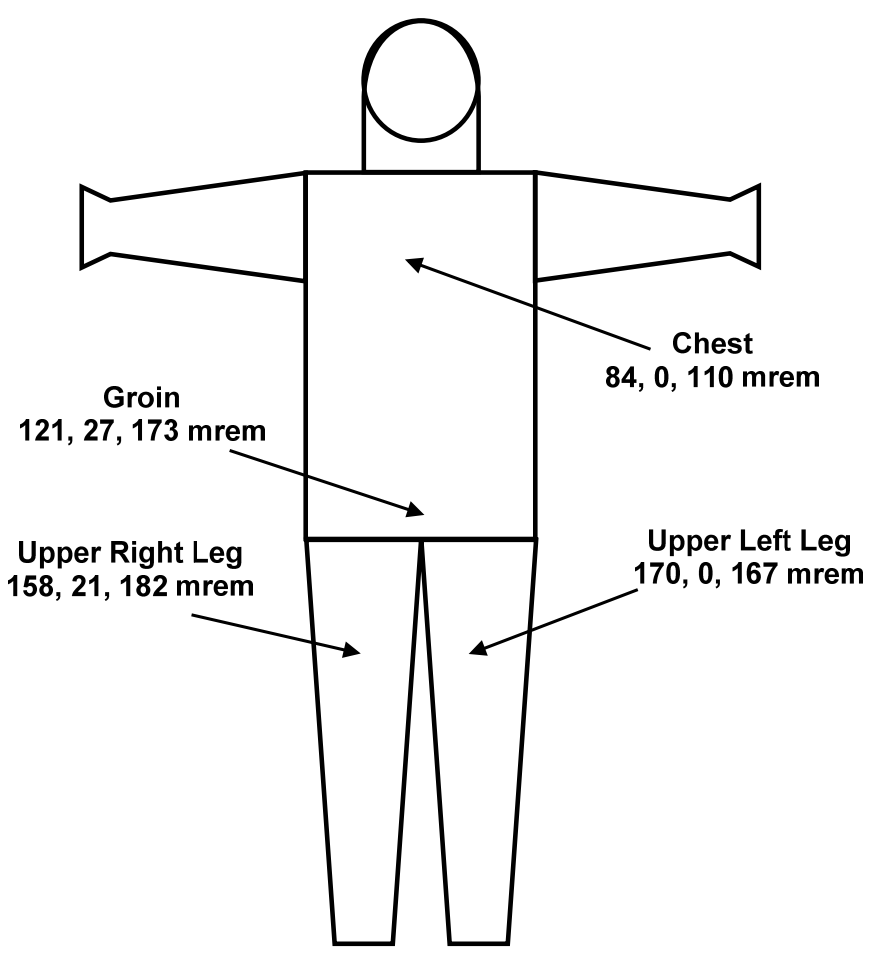

Figure 3. Location of Dosimeters for Example (with deep, neutron, and shallow doses) 
Table 6. Comparison of Effective Dose Using Different Methods for Example

6.A

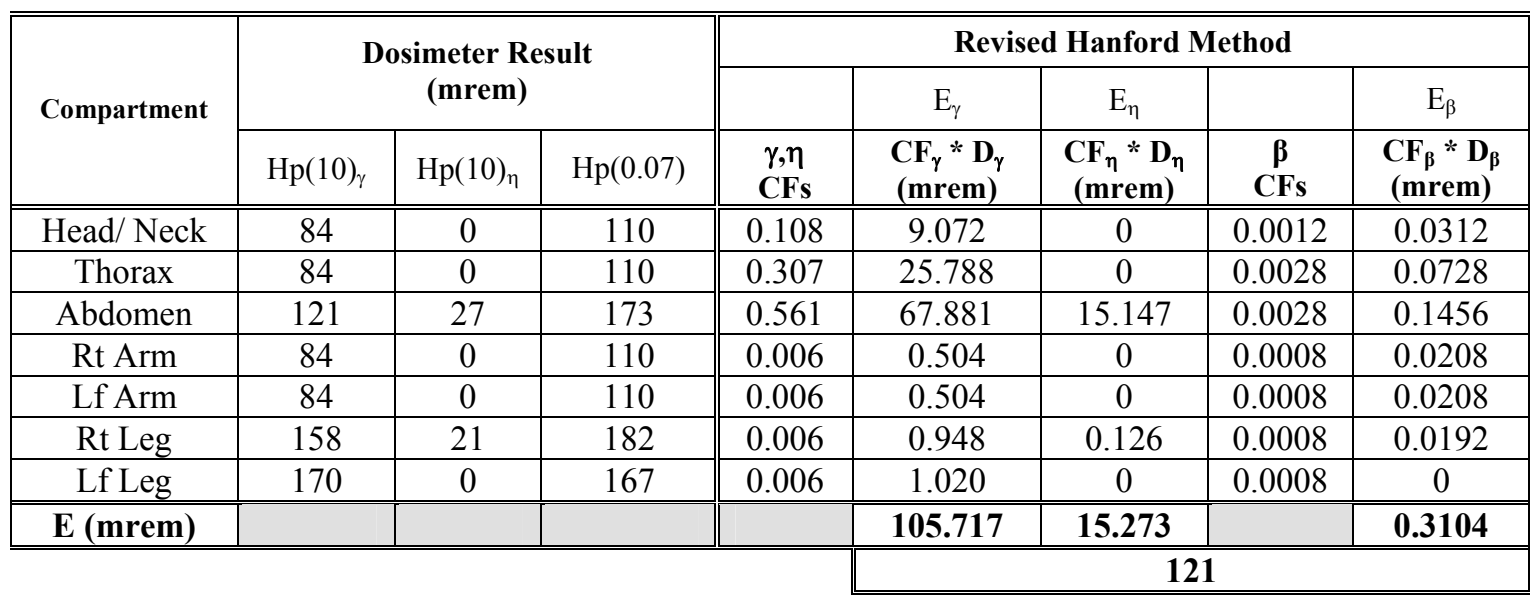

$6 . \mathrm{B}$

\begin{tabular}{|c|c|c|c|c|c|c|c|c|c|c|c|c|}
\hline \multirow{3}{*}{ Compartment } & \multirow{2}{*}{\multicolumn{3}{|c|}{$\begin{array}{l}\text { Dosimeter Result } \\
\text { (mrem) }\end{array}$}} & \multicolumn{3}{|c|}{$\begin{array}{c}\text { Current ANSI/HPS N13.41 and PNL- } \\
\text { MA-842 Values }\end{array}$} & \multicolumn{3}{|c|}{$\begin{array}{c}\text { Draft Revision to } \\
\text { N13.41 Values } \\
\end{array}$} & \multicolumn{3}{|c|}{ Draft MCNP Values } \\
\hline & & & & \multirow[b]{2}{*}{$\begin{array}{l}\gamma, \eta \\
\text { CFs }\end{array}$} & \multirow{2}{*}{$\begin{array}{c}E_{\gamma} \\
\mathbf{C F}_{\gamma} * \mathbf{D}_{\gamma} \\
\text { (mrem) }\end{array}$} & \multirow{2}{*}{$\begin{array}{c}\mathrm{E}_{\eta} \\
\mathbf{C F}_{\eta} * \mathbf{D}_{\eta} \\
(\mathbf{m r e m})\end{array}$} & \multirow[b]{2}{*}{$\begin{array}{l}\gamma, \eta \\
\text { CFs }\end{array}$} & \multirow{2}{*}{$\begin{array}{c}\mathrm{E}_{\gamma} \\
\mathbf{C F}_{\gamma} * \mathbf{D}_{\gamma} \\
\text { (mrem) }\end{array}$} & \multirow{2}{*}{$\begin{array}{c}E_{\eta} \\
\mathbf{C F}_{\eta} * \mathbf{D}_{\eta} \\
(\mathbf{m r e m})\end{array}$} & \multirow[b]{2}{*}{$\begin{array}{l}\gamma, \eta \\
\text { CFs }\end{array}$} & \multirow{2}{*}{$\begin{array}{l}\frac{E_{\gamma}}{\mathbf{C F}_{\gamma} * \mathbf{D}_{\gamma}} \\
(\mathbf{m r e m})\end{array}$} & \multirow{2}{*}{$\begin{array}{c}\frac{E_{\eta}}{\mathbf{C F}_{\eta} * \mathbf{D}_{\eta}} \\
\text { (mrem) }\end{array}$} \\
\hline & $\operatorname{Hp}(10)_{\gamma}$ & $\mathrm{Hp}(10)_{\eta}$ & $\mathrm{Hp}(0.07)$ & & & & & & & & & \\
\hline Head/Neck & 84 & 0 & 110 & 0.10 & 8.40 & 0 & 0.11 & 9.24 & 0 & 0.08 & 6.72 & 0 \\
\hline Thorax & 84 & 0 & 110 & 0.38 & 31.92 & 0 & 0.30 & 25.2 & 0 & 0.29 & 24.36 & 0 \\
\hline Abdomen & 121 & 27 & 173 & 0.50 & 60.50 & 13.5 & 0.57 & 68.97 & 15.39 & 0.62 & 75.02 & 16.74 \\
\hline Rt Arm & 84 & 0 & 110 & 0.005 & 0.42 & 0 & 0.0026 & 0.2184 & 0 & 0.0025 & 0.21 & 0 \\
\hline Lf Arm & 84 & 0 & 110 & 0.005 & 0.42 & 0 & 0.0026 & 0.2184 & 0 & 0.0025 & 0.21 & 0 \\
\hline Rt Leg & 158 & 21 & 182 & 0.005 & 0.79 & 0.105 & 0.0026 & 0.4108 & 0.0546 & 0.0025 & 0.395 & 0.0525 \\
\hline Lf Leg & 170 & 0 & 167 & 0.005 & 0.85 & 0 & 0.0026 & 0.442 & 0 & 0.0025 & 0.425 & 0 \\
\hline E (mrem) & & & & & 103.30 & 13.605 & & 104.6996 & 15.4446 & & 107.34 & 16.7925 \\
\hline & & & & & & & & & & & & \\
\hline
\end{tabular}




\subsection{Discussion}

The DOE "Radiation Protection Programs Guide," was revised in May 2008 to incorporate changes made in the 2007 revision to 10 CFR 835. Section 6.5.1 of that guide provides two acceptable methodologies for determining the dose when multiple dosimeters are worn: (1) use of a compartmentalization methodology that uses the 10 CFR 835 tissue weighting factors to calculate the effective dose of record; or (2) assign the dose from the highest responding dosimeter on the whole body as the effective dose of record. The guide recommends the compartmentalization methodology given in the ANSI/HPS N13.41 standard (1997) as an acceptable method to use. However, the draft revision to the ANSI/HPS N13.41 standard to incorporate the new tissue weighting factors and new list of remainder organs has not yet completed its review or been published. Therefore, new compartment weighting factors were calculated for use at Hanford using the basic methodology presented in the ANSI/HPS N13.41 standard (1997). The tissue weighting factors for all organs/tissues from 10 CFR 835.2 (2007) were used. The tissue weighting factors for the ten remainder organs were calculated based on mass weighting using the remainder organ/tissue masses given in Footnote \#1 to the "Tissue Weighting Factors for Various Organs and Tissues," table in the 10 CFR 835 revision. The fractions of the skin and the muscle that were assumed to be in the whole body (minus the lower extremities, i.e., below the elbow and below the knees) were derived based on data presented in ICRP 23. The revised compartment factors are presented in Table 3.

The example of multiple dosimeter results presented in Section 3.3 illustrates that the effective doses calculated using the new model described here, will increase the reported effective doses for cases where multiple dosimeters are worn from that calculated using the previous model in PNL-MA-842 and the model in ANSI/HPS N13.41 - 1997). The small differences seen in calculated effective dose using the previous PNL-MA-842 method and the three more recent compartment models that reflect changes from ICRP 60 and 10 CFR 835 (2007) are indicative that minor differences in assumptions used to create a compartment model have little effect on the resultant effective dose.

If the option from the DOE Radiation Protection Program Guides is used where the maximum value from the highest dosimeter result in the multiple dosimeter pack was used as the effective dose, then the recorded effective dose could be even higher than for the example given above where a compartment model was used. Actual Hanford multiple dosimeter results for calendar years of 2007 and 2008 were reviewed. There were 288 multiple dosimeter packs in 2007 and 162 packs in 2008. A large portion of those multiple dosimeter packs were composed of dosimeters for chest, groin area, and left and right upper leg. From a sampling of 53 multiple dosimeter packs for these two years, the maximum dosimeter value ranged from $102 \%$ to $260 \%$ of the value reported for the chest dosimeter. Therefore, if the maximum dosimeter value from a multiple dosimeter pack is used as the effective dose, then there is a potential that the effective dose could be over-reported up to 2.6 times when compared to the chest dosimeter results.

The effective dose calculation methodology described here, which uses compartment weighting factors, is recommended as the preferred option for assessing dose from multiple dosimeter packs at Hanford. It is understood that use of the highest whole body dosimeter result for effective dose is also an option since it is always conservative. Whichever method is used by the contractor should be documented in their procedures and identified in the IODR (Investigation of Dosimeter Result) used for updating REX with results from the multi-pack. 


\subsection{References}

American National Standards Institute-Health Physics Society. 1997. Criteria for Performing Multiple Dosimetry. ANSI/HPS N13.41. Health Physics Society, McLean, VA.

International Commission on Radiological Protection (ICRP). 1974. Report of the Task Group on Reference Man. ICRP Publication 23. Pergamon Press, New York.

International Commission on Radiological Protection (ICRP). 1977. Recommendations of the International Commission on Radiological Protection. ICRP Publication 26, New York, New York.

International Commission on Radiological Protection (ICRP). 1991. Radiation Protection: Recommendations of the International Commission on Radiological Protection. ICRP Publication 60, New York, New York.

Pacific Northwest National Laboratory. 2007. Hanford External Dosimetry Technical Basis Manual. PNL-MA-842. PNNL-15750 Rev 0.2, August 29, 2009, PNNL, Richland, WA.

Pacific Northwest National Laboratory. 2010. Hanford External Dosimetry Technical Basis Manual. PNL-MA-842. PNNL-15750 Rev 1.1, May 1, 2010, PNNL, Richland, WA.

U.S. Department of Energy. 1998. Occupational Radiation Protection. DOE 10 CFR 835. Federal Register, November 4, 1998.

U.S. Department of Energy. 2007. Occupational Radiation Protection. DOE 10 CFR 835. Federal Register, June 8, 2007.

U.S. Department of Energy. 2008. Radiation Protection Programs Guide. DOE G 441.1-1C. 